\title{
Erratum: The impact of climate change on disease constraints on production of oilseed rape
}

\author{
Neal Evans • Michael H. Butterworth • Andreas Baierl • \\ Mikhail A. Semenov • Jon S. West • Andrew Barnes • \\ Dominic Moran • Bruce D. L. Fitt
}

Published online: 11 January 2011

(C) Springer Science+Business Media B.V. \& International Society for Plant Pathology 2011

\section{Erratum to: Food Security (2010) 2:143-156 \\ DOI 10.1007/s12571-010-0058-3}

The authors would like to correct a series of errors printed in the above paper. Due to a mistake in a table of official figures with respect to land use in the UK, the figure used for the acreage of oilseed rape produced for Scotland should have been '35 780 ha' and not '398 720 ha' (Table 4). Thus data quoted in the "Results" section of this paper that include this erroneous data (i.e. any "Scottish data" or "total UK" data) are also erroneous by an order of magnitude. Data in the last three lines of the following tables should now read as follows.

Overall, this does not affect the main conclusions of the paper. However, the "Abstract" should now state that the value of the crop (if stem canker and light leaf spot were effectively controlled) was predicted to increase by $£ 2.5 \mathrm{M}$ in Scotland (rather than $£ 28$ M) by 2050 under a high emissions scenario and that under the same scenario, UK disease losses were predicted to increase by $£ 30 \mathrm{M}$ (rather than $£ 50 \mathrm{M}$ ).

The online version of the original article can be found at http://dx.doi. org/10.1007/s12571-010-0058-3.

\footnotetext{
N. Evans $(\varangle) \cdot$ M. H. Butterworth $\cdot$ M. A. Semenov $\cdot$ J. S. West

B. D. L. Fitt

Rothamsted Research,

Harpenden AL5 2JQ, UK

e-mail: neal.evans@bbsrc.ac.uk

\section{A. Baierl}

Department of Statistics and Decision Support Systems,

University of Vienna,

Universitaetsstrasse 5/9,

1010 Vienna, Austria

A. Barnes · D. Moran

Scottish Agricultural College,

West Mains Road,

Edinburgh EH9 3JG, UK
} 
Table 2 Effects of climate change on the output of winter oilseed rape (treated with fungicide), calculated by region. The area grown per region (2006) and the predicted regional output are given for the baseline (1960-1990), 2020LO (low CO $\mathrm{Cm}_{2}$ emissions), 2020HI (high emissions), 2050LO and $2050 \mathrm{HI}$ climate scenarios and presented in thousands of pounds $(£ 000 \mathrm{~s})$. The yield figures were calculated after interpolating the results from the oilseed rape yield predictions according to UK government region and then multiplied by an average price of $£ 195.60 \mathrm{t}^{-1}$

\begin{tabular}{|c|c|c|c|c|c|}
\hline \multirow[t]{2}{*}{ Region $^{\mathrm{a}}$} & \multicolumn{5}{|c|}{ Value of [fungicide treated] oilseed rape crop (£000s) } \\
\hline & Baseline & 2020LO & $2020 \mathrm{HI}$ & 2050LO & $2050 \mathrm{HI}$ \\
\hline North East & 14,098 & 13,168 & 14,536 & 14,646 & 14,812 \\
\hline North West & 2,097 & 2,024 & 1,861 & 2,115 & 2,169 \\
\hline Yorkshire \& Humberside & 37,220 & 35,342 & 38,251 & 38,126 & 38,358 \\
\hline East Midlands & 69,007 & 69,480 & 69,277 & 69,744 & 70,874 \\
\hline West Midlands & 20,194 & 20,121 & 16,839 & 20,900 & 21,726 \\
\hline Eastern & 63,885 & 63,854 & 63,661 & 65,792 & 66,907 \\
\hline London and South East & 46,508 & 46,867 & 46,939 & 48,216 & 49,700 \\
\hline South West & 26,742 & 26,831 & 26,873 & 27,570 & 28,538 \\
\hline England total & 279,749 & 277,688 & 278,237 & 287,110 & 293,085 \\
\hline Scotland & 22,038 & 23,086 & 23,600 & 24,182 & 24,567 \\
\hline UK total & 301,787 & 300,774 & 301,837 & 311,292 & 317,652 \\
\hline
\end{tabular}

${ }^{a}$ Government regions can be found at http://www.statistics.gov.uk/geography/downloads/uk_gor_cty.pdf

Table 3 Effects of climate change on the losses from phoma stem canker and light leaf spot (for cultivars with average resistance) in winter oilseed rape crops not treated with fungicide. The values are given for the baseline (1960-1990), 2020LO (low $\mathrm{CO}_{2}$ emissions), 2020HI (high emissions), 2050LO and $2050 \mathrm{HI}$ climate scenarios and presented in thousands of pounds ( $£ 000 \mathrm{~s}$ ). The figures were calculated after interpolating the results from the stem canker and the light leaf spot yield loss predictions according to UK government region and then multiplied by an average price of $£ 195.60 \mathrm{t}^{-1}$

Value of losses caused by phoma stem canker and light leaf spot $(£ 000 \mathrm{~s})^{\mathrm{b}}$

\begin{tabular}{|c|c|c|c|c|c|}
\hline Region $^{\mathrm{a}}$ & Baseline & 2020LO & $2020 \mathrm{HI}$ & 2050LO & $2050 \mathrm{HI}$ \\
\hline North East & 3,431 & 3,526 & 3,934 & 4,208 & 4,630 \\
\hline North West & 520 & 533 & 501 & 602 & 676 \\
\hline Yorkshire \& Humberside & 7,804 & 8,118 & 9,074 & 9,661 & 10,874 \\
\hline East Midlands & 15,116 & 16,869 & 17,567 & 18,871 & 21,748 \\
\hline West Midlands & 5,038 & 5,539 & 4,716 & 6,244 & 7,308 \\
\hline Eastern & 14,481 & 16,179 & 16,582 & 18,454 & 21,359 \\
\hline London and South East & 12,388 & 13,540 & 13,874 & 15,381 & 17,882 \\
\hline South West & 7,910 & 8,198 & 8,337 & 8,996 & 10,191 \\
\hline England total & 66,690 & 72,502 & 74,584 & 82,417 & 94,668 \\
\hline Scotland & 7,109 & 7,663 & 7,901 & 10,240 & 9,067 \\
\hline UK total & 73,890 & 80,165 & 82,485 & 92,657 & 103,735 \\
\hline
\end{tabular}

${ }^{a}$ Government regions can be found at http://www.statistics.gov.uk/geography/downloads/uk_gor_cty.pdf

${ }^{\mathrm{b}}$ The stem canker and light leaf spot loss predictions depend on the crop yield predictions in Table 2 
Table 4 Effects of climate change on the yield of untreated oilseed rape after phoma stem canker and light leaf spot losses, calculated by region. The area grown per region (2006) and the predicted total regional yield are given for the baseline (1960-1990) scenario. The total regional yield as a percentage of the baseline scenario is given for the 2020LO (low $\mathrm{CO}_{2}$ emissions), 2020HI (high emissions), 2050LO and 2050HI climate scenarios. The figures were calculated after interpolating the results from the treated oilseed rape yield predictions, the stem canker yield loss predictions and the light leaf spot loss predictions according to UK government region

\begin{tabular}{|c|c|c|c|c|c|c|}
\hline \multirow[t]{2}{*}{ Region $^{\mathrm{a}}$} & \multirow[t]{2}{*}{ Area of oilseed rape grown $(\mathrm{ha})^{\mathrm{b}}$} & \multirow[t]{2}{*}{ Baseline total yield $(\mathrm{t})$} & \multicolumn{4}{|c|}{ Yield (\% of baseline yield) } \\
\hline & & & 2020LO & $2020 \mathrm{HI}$ & 2050LO & $2050 \mathrm{HI}$ \\
\hline North East & 22,787 & 72,649 & 90.4 & 99.4 & 97.9 & 95.5 \\
\hline North West & 3,601 & 10,769 & 94.5 & 86.2 & 96.0 & 94.7 \\
\hline Yorkshire \& Humberside & 61,068 & 189,125 & 92.6 & 99.2 & 96.8 & 93.4 \\
\hline East Midlands & 113,479 & 342,630 & 97.6 & 96.0 & 94.4 & 91.2 \\
\hline West Midlands & 34,419 & 97,510 & 96.2 & 80.0 & 96.7 & 95.1 \\
\hline Eastern & 103,488 & 309,496 & 96.5 & 95.3 & 95.8 & 92.2 \\
\hline London and South East & 79,063 & 219,128 & 97.7 & 96.9 & 96.2 & 93.3 \\
\hline South West & 44,858 & 127,461 & 98.9 & 98.4 & 98.6 & 97.4 \\
\hline England total & 462,764 & $1,368,770$ & 96.3 & 95.6 & 96.1 & 93.1 \\
\hline Scotland & 35,780 & 76,324 & 103.3 & 105.2 & 93.4 & 103.8 \\
\hline UK total & 498,544 & $1,445,094$ & 99.4 & 99.8 & 94.9 & 97.8 \\
\hline
\end{tabular}

${ }^{a}$ Government regions can be found at http://www.statistics.gov.uk/geography/downloads/uk_gor_cty.pdf

${ }^{\mathrm{b}}$ Area of winter oilseed rape grown in each region in harvest year 2006 (www.defra.gov.uk)

Table 5 Effects of climate change on the output of untreated winter oilseed rape (for cultivars with average resistance) after phoma stem canker and light leaf spot losses, calculated by region. The area grown per region (2006) and the predicted regional output are given for the baseline (1960-1990), 2020LO (low emissions), 2020HI (high emissions), 2050LO and 2050HI climate scenarios and presented in thousands of pounds $(£ 000 \mathrm{~s})$. The figures were calculated after interpolating the results from the treated oilseed rape yield predictions, the stem canker yield loss predictions and the light leaf spot loss predictions according to UK government region and then multiplied by an average price of $£ 195.60 \mathrm{t}^{-1}$

\begin{tabular}{|c|c|c|c|c|c|}
\hline \multirow[t]{2}{*}{ Region $^{\mathrm{a}}$} & \multicolumn{5}{|c|}{ Value of [untreated] oilseed rape crop ( $£ 000 \mathrm{~s})$} \\
\hline & Baseline & 2020LO & $2020 \mathrm{HI}$ & 2050LO & $2050 \mathrm{HI}$ \\
\hline North East & 10,666 & 9,642 & 10,602 & 10,438 & 10,182 \\
\hline North West & 1,576 & 1,490 & 1,359 & 1,513 & 1,493 \\
\hline Yorkshire \& Humberside & 29,415 & 27,224 & 29,177 & 28,466 & 27,484 \\
\hline East Midlands & 53,891 & 52,612 & 51,711 & 50,873 & 49,126 \\
\hline West Midlands & 15,155 & 14,582 & 12,123 & 14,656 & 14,418 \\
\hline Eastern & 49,404 & 47,676 & 47,080 & 47,338 & 45,548 \\
\hline London and South East & 34,120 & 33,327 & 33,065 & 32,835 & 31,818 \\
\hline South West & 18,831 & 18,633 & 18,536 & 18,574 & 18,348 \\
\hline England total & 213,059 & 205,186 & 203,653 & 204,693 & 198,417 \\
\hline Scotland & 14,929 & 15,423 & 15,699 & 13,942 & 15,500 \\
\hline UK total & 227,988 & 220,609 & 219,352 & 218,635 & 213,917 \\
\hline
\end{tabular}

${ }^{\text {a }}$ Government regions can be found at http://www.statistics.gov.uk/geography/downloads/uk_gor_cty.pdf

${ }^{\mathrm{b}}$ Area of winter oilseed rape grown in each region in harvest year 2006 (www.defra.gov.uk) 
Table 6 Present value of the effects of climate change (£000s)

Present value of the effects of climate change ( $£ 000 \mathrm{~s})$

\begin{tabular}{|c|c|c|c|c|c|}
\hline Region $^{\mathrm{a}}$ & Scenario & $2020 \mathrm{LO}$ & $2020 \mathrm{HI}$ & $2050 \mathrm{LO}$ & $2050 \mathrm{HI}$ \\
\hline North East & & -678 & -43 & -66 & -140 \\
\hline North West & & -57 & -143 & -18 & -24 \\
\hline Yorkshire \& Humberside & & $-1,450$ & -158 & -274 & -558 \\
\hline East Midlands & & -846 & $-1,443$ & -872 & $-1,377$ \\
\hline West Midlands & & -379 & $-2,007$ & -144 & -213 \\
\hline Eastern & & $-1,144$ & $-1,538$ & -597 & $-1,114$ \\
\hline London and South East & & -525 & -698 & -371 & -665 \\
\hline South West & & -131 & -195 & -74 & -140 \\
\hline England total & & $-5,210$ & $-6,225$ & $-2,417$ & $-4,231$ \\
\hline Scotland & & 327 & 510 & -285 & 165 \\
\hline UK total & & $-4,883$ & $-5,715$ & $-2,703$ & $-4,066$ \\
\hline
\end{tabular}

${ }^{a}$ Government regions can be found at http://www.statistics.gov.uk/geography/downloads/uk_gor_cty.pdf 